\title{
水蒸気をキャリヤーガスとした炭化水素試料の 気-固クロマトグラフィー*
}

\author{
野 中 昭**
}

(1970 年 9 月 3 日受理)

水蒸気をキャリヤーガスとし, 活性アルミナを固定相とする気一固クロマトグラフィーによって, $\mathrm{C}_{5} \sim \mathrm{C}_{9}$ の直鎖炭化水素，リグロイン，ベンゼンとその誘導体の分離分析を試みた。分離管は $2 \mathrm{~mm} \times$ $3 \mathrm{~m}, 40 \sim 60$ メッシニの活性アルミナ，分離管温度は $120 \sim 220^{\circ} \mathrm{C}$, キャリャー 水蒸気の流速は 5〜 $20 \mathrm{ml} / \mathrm{min}$, 試料洔すべて $0.1 \%$ 以下の水乳化液として注入された。保持容量は $180^{\circ} \mathrm{C} て ゙, n$-ペンタ ン : $40 \mathrm{ml}, n$-オクタン $: 323 \mathrm{ml}$, ベンゼン : $116 \mathrm{~m} l, o$-キシンン $: 466 \mathrm{ml}$ であり, 理論段数は 1000 1400 段が得られ，流出ピークの形は正常であった。保持容量は，分離管温度の上昇とともに増加する 温度範囲があり，本実験によるクロマトグラフィーが，通常の気一固クロマトグラフィーと非常に異な る機構を有することを推測させた。

\section{1 緒言}

水蒸気をキャリヤーガスと方る吸着ガス（気一固）ク ロマトグラフィーが，有機物一般の試料について有効で あることはすでに報告したが1 ら)，この報文では炭化水 素試料について得られた結果を, やや詳しく述べる.

不活性ガスをキャリヤーガスとする従来の気一固ク口 マトグラフィーでは, 炭化水素類の試料に対しては, 通 常炭素数が 4 以下の, 室温でガス状の物質のみが対象と され, 室温以上の沸点を有寸る炭化水素試料注気一液ク ロマトグラフィーによるのが普通であった. しかるに水 蒸気をキャリヤーガスとするとき，活性アルミナなどを 固定相としても，炭素数 5 以上の比較的沸点の高い炭化 水素類をも容易に分離・流出させうることがわかった。

炭化水素試料を対象として, 気一固クロマトグラフィ 一のキャリヤーガスに少量の水蒸気を混入して試料の流 出速めることは，さきに例外的に試みられているが6， 水蒸気を単独でキャリヤーガスに利用した気一固クロマ トグラフィーの例はこれまで報告されていない。また， 水を固定相とする気一液クロマトグラフィーで高沸点の 炭化水素を分析した例が報告されているが，この場合も

* 水蒸気をキャリヤーガスとした有機試料の吸着ガス クロマトグラフィー（第 4 報）。前報は野中 昭 : 本誌, 17, 1215 (1968)

** 東京教育大学光学研究所 : 東京都新宿区百人町 4 丁 目
キャリヤーガスは水蒸気一ヘリウム混合ガスを用い, 分 離管温度を水蒸気の凝縮温度に設定し, 明らかに気-液 クロマトグラフィーとして操作させている78).

従来のガスクロマトグラフィーでは, 試料に水を含む と, 流出ピークの形の不斉, 分離管の劣化などクロマト グラフィーの適用に困難をともなう場合が多く, 特に 気一固クロマトグラフィーの場合には, 水分がそのクロ マトグラムに及ぼす影響㵔しいものがあったが，本方 法で水蒸父がキャリヤーガスであるため, 試料中の水 分はそのクロマトグラムになえらの影響も与えない. 水 の中に乳化，あるい法可溶化されている炭化水素試料で あっても, その濃度が 1 ppm 程度宋ではとのままで本 方法が適用可能である.また本方法で使用する固定相は アルミナ, シリカなどであるから，一般に熱に強く使用 中の経時変化はきわめて少ない、また分離管の保存にあ たっても，吸湿などによる变質は考元られない，

本方法は水蒸気をキャリヤーガスとする気一固クロマ トグラフィーであるが，そのクロマトグラフィーが行な われる機構法従来の気一固クロマトグラフィーといくぶ 几異なっているものと推測される. その大きな特徴は, 保持容量が必ずしも分離管の温度とともに減少しないこ とである、これはキャリヤーガスが㠜縮性ガスのため固 定相表面に数分子層にわたって吸着され，試料分子はそ の上に吸着されて，移動するものと考えられる、したが って, 試料ガスはもとの固定相表面の影響を受けはする が，単に固定相表面に吸着されたり，溶解したりするの 


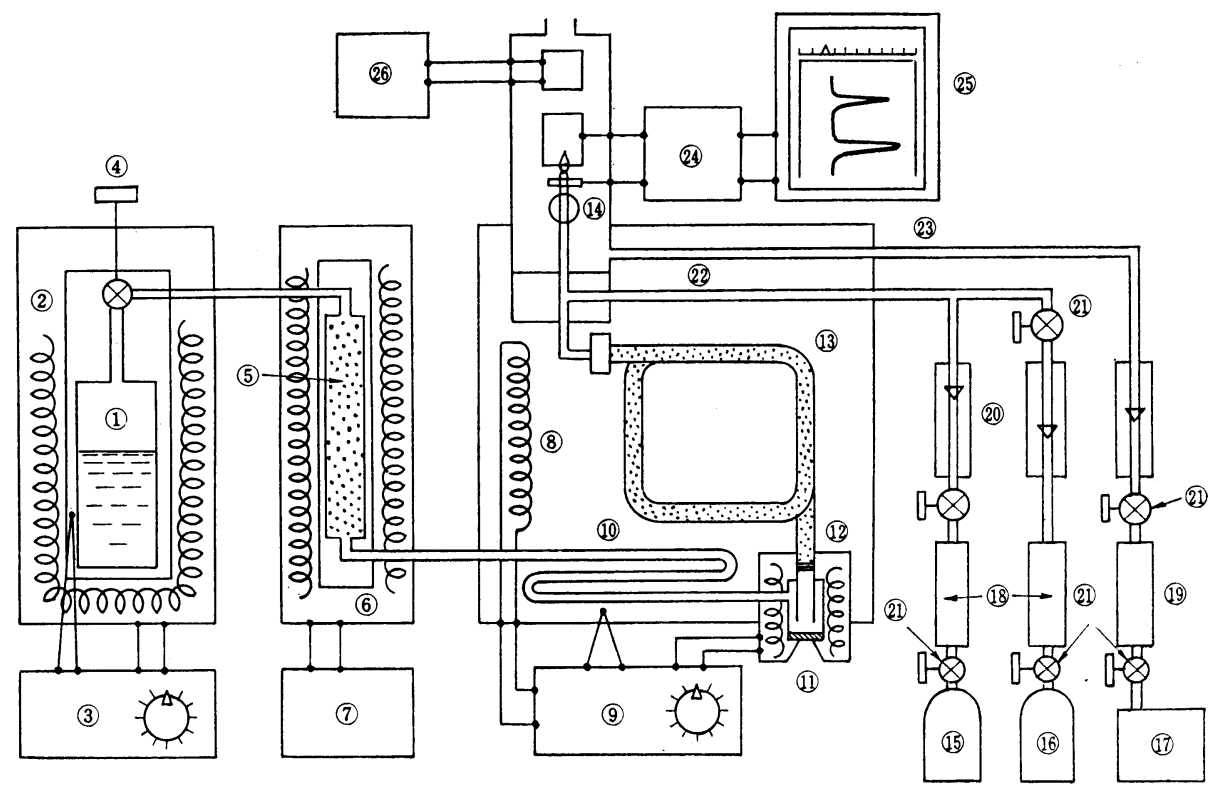

Fig. 1 Schematic diagram of the steam carrier G-S chromatograph

(1) Steam boiler; (2) Electric furnace; (3) Thermoregulator for the boiler; (4) Needle valve; (5) CuO pellet column; (6) Furnace for the CuO column; (7) Voltage regulator; (8) Regulated air bath; (9) Thermoregulator for the air bath; (10) Stream buffer; (11) Sample inlet; (12) Sample evaporator; (13) Analytical column; (14) H-flame ionization detector; (1i) Hydrogen cylinder; (16) Nitrogen cylinder; (17) Air blower; (18) Silica gel column; (19) Molecular sieves column; (20) Rotameter; (21) Reducing valve; (29) Fuel gas for the detector; (23) Scavenging air; (29) D. C. amplifier; (25) Chromatogram recorder; (26) Dew-point meter for measuring the carrier flow rate

ではないと解釈される。

本報交では，固定相に活性アルミナ，試料として $\mathrm{C}_{5} \sim$ $\mathrm{C}_{9}$ の直鎖炭化水素, 石油留分, ベンゼンとその誘導体 などの水乳化液を使用した例を報告する.

\section{2 装置}

本研究では，分離管を除いては，これまで汇報告した 水蒸気をキャリヤーガスとした吸着ガスクロマトグラフ イーの研究1 尚に用いた装置とほぼ同一の装置を使用し た.すなわち, 大倉理化学研究所製, Model 2000 大倉 水素炎ガスクロマトグラフを基体とし，これに水蒸気発 生用ボイラーなどを付加して使用した。装置全体の略図 を Fig. 1 に示す.

\section{1 キャリャーガス導入部}

水蒸気発生用ボイラーは, 内径 $45 \mathrm{~mm}$, 高さ $90 \mathrm{~mm}$ のステンレス鋼製容器で，これを $120 \sim 140^{\circ} \mathrm{C}$ の間の一 定温度に保ち, 発生する一定压の水蒸気をニードルバル ブによって流量を調節したのち, ボイラー温度以上に保 った導入パイプを用いて分離管頂に導く。導入パイプ の途中に $500 \sim 600^{\circ} \mathrm{G}$ に保った酸化銅ペレットカラム $(5 \mathrm{~mm} \phi \times 50 \mathrm{~cm})$ を抒いて, ボイラー水中の有機不純物 を除いた。試料の注入は，マイクロシリンジにより，厚 さ約 $3 \mathrm{~mm}$ のシリコンゴムセプタムを突き刺して行なう
が，この注入口付近の保温を確実にしておくことが必要 である。

\section{2 分離管}

分膗管用パイプには，硬質ガラスおよびフルミニウム 管を用いた。内径が $2 \mathrm{~mm}$ の分離管と $4 \mathrm{~mm}$ の分離管 によって実験を行なったが， $4 \mathrm{~mm}$ のものは $2 \mathrm{~mm} の$ ものに比べて，分離がかなり劣ったので，以下にあげる 結果はすべて内径 $2 \mathrm{~mm}$ の分離管によるものである. 分 離管の長さ㤝打も $3 \mathrm{~m}$ を使用した。

固定相には，ガスクロマトグラフ用活性フルミナ（ガ スクロ工業製, $40 \sim 60$ メッシュ, 表面積約 $300 \mathrm{~m}^{2} / \mathrm{g}$ ) を使用した。

\section{3 検出器}

水素炎イオン化検出器を用いた。水素ガス $(30$ ７0 $\mathrm{m} l / \mathrm{min})$ にはあらかじめ窒素ガス $(20 \sim 50 \mathrm{ml} / \mathrm{min})$ を

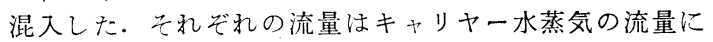
応じて，感度が最大になるょうに調節した。窒素を混入 しないと感度はかなり低くなる。

\section{3 実験および結果}

\section{1 試料およびその調製}

試料には次のものを用いた。 
(a)

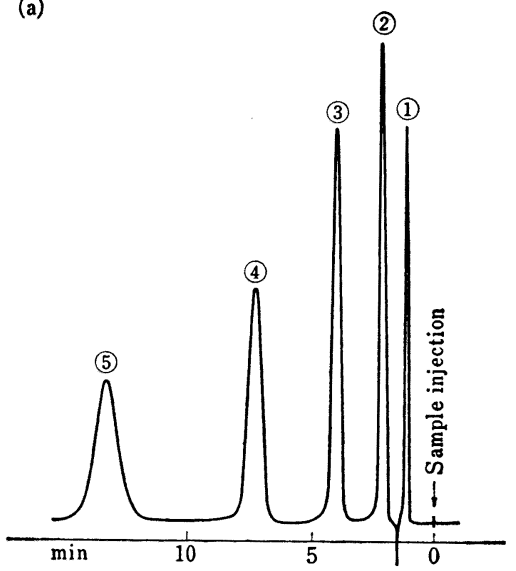

(b)

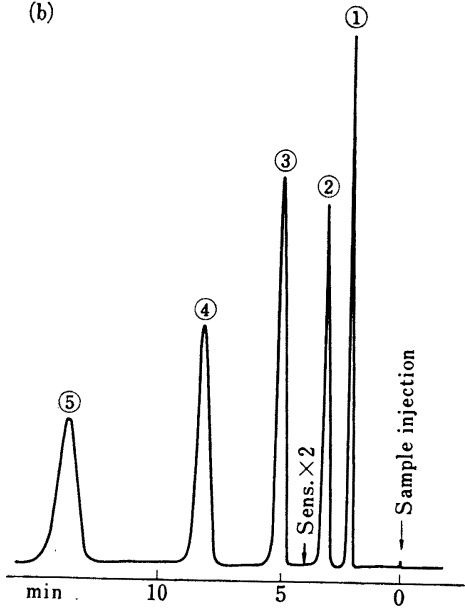

Fig. 2 Chromatogram of alkanes in $0.01 \%$ aqueous emulsion by steam carrier G-S chromatogi aphy

(1) $n-\mathrm{C}_{5} \mathrm{H}_{12}$ (Sens. $\times 1 / 2$ ); (2) $n-\mathrm{C}_{6} \mathrm{H}_{14}$; (3) $n-\mathrm{C}_{7} \mathrm{H}_{16}$; (4) $n-\mathrm{C}_{8} \mathrm{H}_{18}$; (5) $n-\mathrm{C}_{9} \mathrm{H}_{20}$; Column : Activated alumina, $40 \sim 60 \mathrm{mesh}$, aluminum tube, $2 \mathrm{~mm} \times 3 \mathrm{~m}$; Column temp. : (a) $122^{\circ} \mathrm{C}$, (b) $222^{\circ} \mathrm{C}$; Carrier gas : Steam, (a) $18 \mathrm{ml} / \mathrm{min}$, (b) $10 \mathrm{ml} / \mathrm{min}$; Detector : Hydrogen flame ionization

$\mathrm{C}_{5} \sim \mathrm{C}_{9}$ の直鎖炭化水素, ベンゼン, トルエン, 3 種 の異性体を含むキシレン, $130 \sim 145^{\circ} \mathrm{C}$ の石油留分（リ グロイン).

上記の炭化水素はすべて少量の界面活性剂（アルキル ベンゼンスルホン酸ナトリウムなど）堂滦加し，ホモジ ナイザーを用いて $0.1 \%$ 1 ppm の水乳化液に調製して 実験用試料とした，分離を試験するためにはこれらの試 料を混合して用いた。

\section{2 クロマトグラフィーの諸条件}

試料蒸発部の温度は $200 \sim 350^{\circ} \mathrm{C}$, 分離管の温度は $110 \sim 260^{\circ} \mathrm{G}$ の一定温度で実験を行なった，昇温法は試 タなかった。

水蒸気キャリヤーガスの流量は 5〜20 $\mathrm{ml} / \mathrm{min}$ の範囲 であった。

試料の注入量は $1 \mu l$ で全量 $1 . \mu l \mu$ のマイクロシリン ジを用いた。

\section{3 クロマトグラム}

得られたクロマトグラムの例を Fig. 2〜 5 に示す.

Fig. 2 (a) および（b） は $\mathrm{C}_{5} \sim \mathrm{C}_{9}$ の直鎖炭化水素混合 試料 $\left(0.01 \%\right.$ 水乳化液) で分離管温度 $122^{\circ} \mathrm{C}$ および $220^{\circ} \mathrm{C}$ に拧けるクロマトグラムである. 両者とも流出ピ 一クの形状は正常であり，分離もよい. Fig. 2 (a)，(b) 両図に打いて分離管温度の差は非常に大きいにもかかわ らず，保持容量，理論段数などに大きな差が見られない

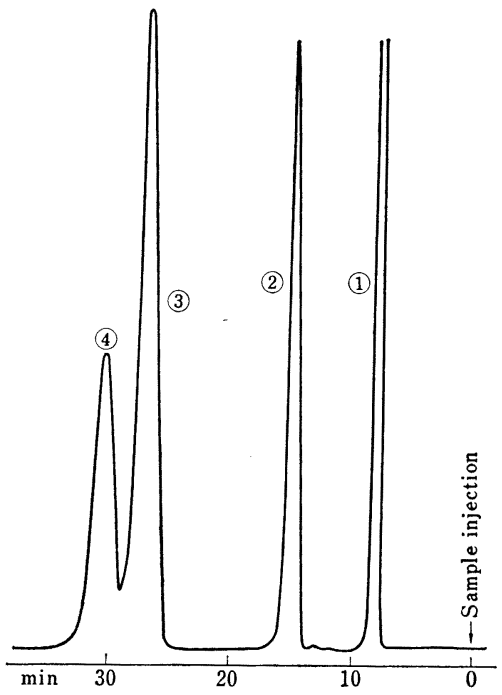

Fig. 3 Chromatogram of benzene and its derivatives in $0.1 \%$ aqueous emulsion by steam carrier G-S chromatography

(1) Benzene; (2) Toluene; (3) $m-, p$-Xylene; (4) $o-$ Xylene; Column: Activated alumina, 40 60 mesh, aluminum tube, $2 \mathrm{~mm} \times 3 \mathrm{~m}$; Column temp. : $180^{\circ} \mathrm{C}$; Carrier gas: Steam, $17 \mathrm{~m} / \mathrm{min}$; Detector : Hydrogen flame ionization

のは，このクロマトグラフィーにおける大きな特徵であ る. Fig. 3 はベンゼン, トルェン, キシレン（3 種の異 性体を含导）の混合試料 $\left(0.1 \%\right.$ 水乳化液） O $180^{\circ} \mathrm{C}$ 


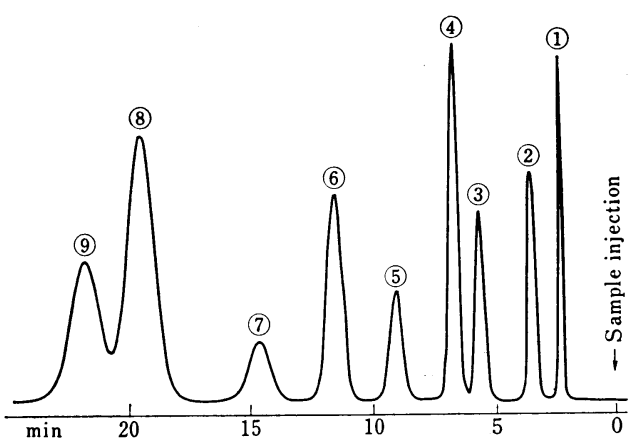

Fig. 4 Chromatogram of alkanes and benzenederivatives in aqueous emulsion by steam carrier G-S chromatography

(1) $n$-Pentane; (2) $n$-Hexane; (3) $n$-Heptane; (4) Benzene; (5) $n$-Octane; (6) Toluene; (7) $n$-Nonane; (8) $p-, m$-Xylene; (9) $o$-Xylene; Column: Activated alumina, 40 60 mesh, aluminum tube, $2 \mathrm{~mm} \times 3 \mathrm{~m}$; Column temp. : $125^{\circ} \mathrm{C} ; \quad$ Carrier gas : Steam, $12 \mathrm{ml} /$ min; Detector : Hydrogen flame ionization

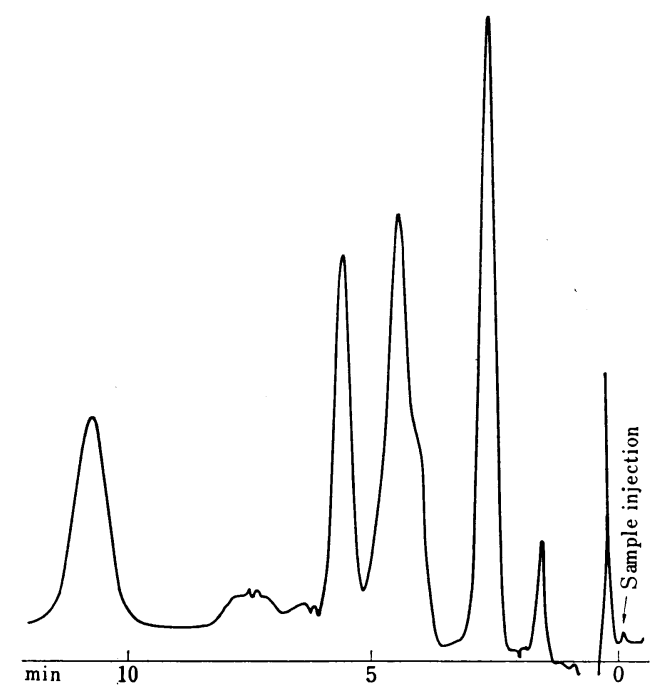

Fig. 5 Chromatogram of ligroin in $0.01 \%$ aqueous emulsion by steam carrier G-S chromatography

Column : Activated alumina, 40 60 mesh, aluminum tube, $2 \mathrm{~mm} \times 2.6 \mathrm{~m}$; Column temp. : $140^{\circ} \mathrm{C}$; Carrier gas : Steam; Detector : Hydrogen flame ionization

におけるクロマトグラムである. 前例と同じく良好な流 出ピークが見られる.これらの試料に対しては $180^{\circ} \mathrm{G}$ 前後の 分離管温度で最もよい分離が得られるのである が，p-キシレンと $m$-キシレンはまったく分離できなか った.このクロマトグラフィーでは, 芳香族炭化水素と
直鎖炭化水素とでは，同程度の沸点を有しても前者のほ うが後者よりはるかに大きい保持時間を有するが，この 傾向は低いカラム温度のときほど大きくなる．この例と して $125^{\circ} \mathrm{C}$ に打りる芳香族炭化水素と直鎖炭化水素の 混合試料の分離を Fig. 4 に示した. Fig. 5 は石油留分 $\left(130 \sim 145^{\circ} \mathrm{C}\right)$ のクロマトグラムの例である.

本実験に使用した試料については，分離管温度 $120^{\circ} \mathrm{C}$ 以上ではほぼ満足すべき分離が得られたが，それ以下の 温度ではこれらの試料に対して保持時間が極端に減少 し，分離も著しくわるくなった。

\section{4 保持容量}

Table I に，種々の分離管温度における保持容量を示 す。保持容量と温度との関係では，分離管温度を上げて も必ずしも保持容量が減少せず，かえって増加する温度 範囲がある・低温（約 $120^{\circ} \mathrm{C}$ ) におけるクロマトグラム と, 高温（約 $220^{\circ} \mathrm{C}$ ）におけるそれとにあまり差が見ら れないのはこの現象による.

本実験に打ける水蒸気キャリヤ一気一固クロマトグラ フィーでは，これまでに報告された水蒸気キャリヤー 気一固クロマトグラフィーの場合に比べると，保持容量 の值は比較的大きい.

Table I Retention volumes at various column tempepatures

\begin{tabular}{lcccc}
\hline \multirow{2}{*}{ Sample } & \multicolumn{4}{c}{ Temp. } \\
\cline { 2 - 5 } & $125^{\circ} \mathrm{C}$ & $140^{\circ} \mathrm{C}$ & $180^{\circ} \mathrm{C}$ & $220^{\circ} \mathrm{C}$ \\
\hline$n$-Pentane & $35 \mathrm{~m} l$ & $33 \mathrm{~m} l$ & $40 \mathrm{~m} l$ & $36 \mathrm{~m} l$ \\
$n$-Hexane & 53 & 54 & 62 & 52 \\
$n$-Heptane & 84 & 91 & 106 & 85 \\
$n$-Octane & 140 & 158 & 180 & 137 \\
$n$-Nonane & 233 & 274 & 323 & 230 \\
Benzene & 104 & 105 & 116 & 95 \\
Toluene & 184 & 210 & 218 & 170 \\
$p$-, m-Xylene & 316 & 395 & 411 & 293 \\
$o$-Xylene & 361 & 456 & 466 & 334 \\
\hline
\end{tabular}

Column : Activated alumina, $40 \sim 60 \mathrm{mesh}, 2 \mathrm{~mm} \times 3 \mathrm{~m}$

Table II The number of theoretical plates

\begin{tabular}{lcccc}
\hline \hline \multirow{2}{*}{ Sample } & \multicolumn{4}{c}{ Temp. } \\
\cline { 2 - 5 } & $120^{\circ} \mathrm{C}$ & $140^{\circ} \mathrm{C}$ & $180^{\circ} \mathrm{C}$ & $220^{\circ} \mathrm{C}$ \\
\hline$n$-Heptane & 900 & 1160 & 930 & 1300 \\
$n$-Octane & 800 & 1100 & 1100 & 1500 \\
$n$-Nonane & 850 & 1150 & 1000 & 1200 \\
Benzene & 620 & - & 1200 & 1080 \\
Toluene & 1020 & - & 1360 & 1580 \\
$m$-, $p$-Xylene & 1160 & - & 1460 & 1340 \\
$o$-Xylene & 1220 & - & 1430 & 1400 \\
\hline
\end{tabular}

Column: Activated alumina, $40 \sim 60 \mathrm{mesh}, 2 \mathrm{~mm} \times 3 \mathrm{~m}$ 


\section{5 理論段数}

Table II に，クロマトグラムより 算出された 理論段 数の例を示す. Table II によると, 一般にカラム温度 が高いほうが理論段数が大きくなる傾向がある.

\section{4 考察}

\section{1 保持容量と温度との関係の異常性}

これまでのガスクロマトグラフィーでは，気-固クロ マトグラフィーであっても, 気一液クロマトグラフィー であっても，保持容量の対数と分離管温度（絶対温度） の逆数はほぼ直線関係を保つことが実験で示され (Fig. 6 の点線), この事実はまた理論的にも説明がなされた。

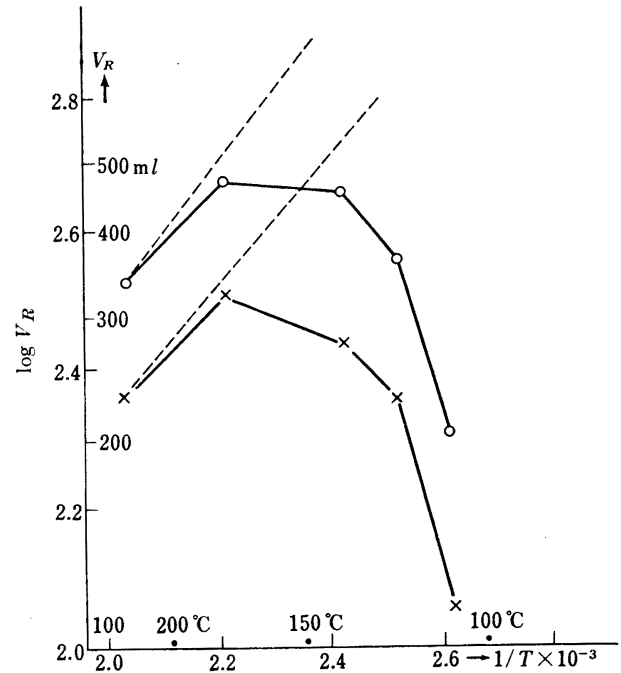

Fig. 6 Temperature dependence of the retention volume in the steam carrier G-S chromatography

-O- o-Xylene; $-x-n$-Nonane; Column: Activated alumina; Samples : $o$-Xylene and $n$-nonane

すなわち, 保持容量を $V_{R}$, 分離管温度を $T$, 吸着熱 （気一固クロマトグラフィーの場合）または溶解熱（気一 液クロマトグラフィーの場合）を $h$ とするとき

$$
V_{R}=c \exp \frac{-h}{R T}
$$

ただし， $R$ : 気体定数， $c$ 注比例定数.

となる.しかるに本実験における気一固クロマトグラフ ィーでは, $\log V_{R}$ と $1 / T$ との関係では正のこう配をも つ直線関係はなりたっていない (Fig. 6 の実線). この 現象は次のような説明によって理解されるであろう。す
なわち，水蒸気キャリヤ一気一固クロマトグラフィーで は，固定相表面にかなり厚く，数分子層にわたり水蒸気 が吸着されているものと推定される，この推定は，臨界 温度以下の気体に対する B. E.T. (Brunauer, Emmett, Teller) の吸着理論*9)10) によって裏づけられる。しか もこの理論によると, 気相中の水蒸気圧がとの温度にお ける飽和蒸気圧に近いときにはとの吸着層は非常に厚 く，飽和蒸気圧から離れると急激に吸着層の厚さが減少 することが示される. 水蒸気 キャリヤ一気固クロマト グラフィーでは，試料分子はこの水吸着層の上に吸着さ れて吸着クロマトグラフィーが行なわれると考えられる が，そのときの吸着エネルギーは，吸着水との相互作用 と，吸着水を介しての吸着郕表面との相互作用エネルギ 一と, 両方の和であると推測される. 試料分子と吸着剂 表面との直接の相互作用エネルギーはもともとかなり大 きく11)，そのため不活性キャリヤーガスでは試料は容易 に流出しない。しかし，水蒸気キャリヤーガスを用いる と, 前述のようにかなり厚い水吸着層ができて, 試料分 子に対する吸着エネルギーを減少させるのであるが，こ の水吸着層の厚さがカラム温度によって（おもにその温 度における飽和蒸気压との比が変わるため）著しく変わ るので，試料に対する吸着エネルギーもまた著しく変わ るものとせねばならない。ここにおいて，試料の固定相 （水吸着層上）に対する吸着エネルギーはもはや一定で なく\{良来のガスクロマトグラフィーでは (4-1) 式に おけるh温度にかかわらず一定とみなされる\}, 温度 によって著しく変化するものと考えられる，したがっ て，(4-1) 式において，すでに $h$ は一定でなくTの関数 であるから， $\log V_{R}$ と $1 / T$ との関係は直線になること は期待できない，また $T$ の増加による一 $h$ の増加が $R T$ を上まわる場合には，Tの増加によって $V_{R}$ がかえって 増加する場合があることが予想される.これによって， 本実験における分離管温度と保持容量の関係の異常性が 説明される. また分離管温度が $120^{\circ} \mathrm{C}$ 以下では試料の 流出が極端に速くなるのは，水吸着層の厚さが相当に愿 くなり，試料は固定相下地の影響をほとえど受けなくな って，吸着エネルギーもまた著しく減少するためと考え られる。

* B. E. T. 吸着式 :

$$
\theta=\frac{c p}{\left(p_{0}-p\right)\left\{1+(c-1) \frac{p}{p_{0}}\right\}}, c=\exp \frac{h_{1}-h_{v}}{R T}
$$

ただし， $\theta$ : 吸着被覆率, $p$ : 平衡蒸気圧, $p_{0}$ : 飽 和蒸気压（温度 $T$ における）, $h_{1}$ : 蒸気の第 1 層吸 着熱, $h_{0}$ : 蒸父の液化熱. 


\section{5 結語}

水蒸気をキャリヤーガスとする気一固クロマトグラフ ィーによって，極性有機物試料であっても．無極性有機 物試料であっても，ともに有効に分離・分析が可能であ ることがわかった．この方法による長所は，固定相とし て安定な無機質の吸着剤が使用できること, 試料として 含水試料がかなり濃度の低いものまで使用できるという ことである，分離管の保存についても吸湿などによる变 質はなく, その他の污損についても水蒸気洗浄によって 比較的簡単に回復する.

水蒸気キャリヤー気-固クロマトグラフィーの機構と して，水蒸気の固定相上への多分子層吸着が考慮された が，これはキャリャーガスに蒸気（臨界温度以下の温度 における気体）を使用すれば必ず見ら机る現象であるか ら，キャリヤーガスに水蒸気以外の種々の蒸気を用いた 気一固クロマトグラフィーを試みても，それぞれ興味あ る結果が期待されるであろう.

(1968 年 10 月，本会第 17 年会に打いて発表)

\section{交献}

1) 野中 昭: 本誌, 16, 260 (1967).

2) 野中 昭: 同上, 16, 1166 (1967).

3) 野中 昭: 同上, 17, 91 (1968).

4) 野中 昭: 同上, 17, 944 (1968).

5) 野中 昭 : 同上, 17, 1215 (1968).

6) I. Halâsz, E. Heine : Anal. Chem., 37, 495 (1965).
7) B. L. Karger, A. Hartkopf : ibid., 40, 215 (1968).

8) B. L. Karger, A. Hartkopf, H. Postmanter : J. Chromatog. Sci., 7, 315 (1969).

9) S. Brunauer, P. H. Emmett, E. Teller : $J$. Am. Chem. Soc., 60, 309 (1938).

10）高石哲男，古山昌三訳（ヤング，クロウェル著）： “ガスの物理吸着”， p. 136 (1967)，（産業困 書).

11) V. H. Spannheimer, H. Knözinger : Ber. Bunsenges. Phys. Chem., 70, 575 (1966).

is

Steam carrier gas-solid chromatography of hydrocarbons. Akira NoNAKA (Institute for Optical Research, Kyôiku University, Shinjuku-ku, Tokyo)

A G-S chromatography was applied to the analyses of hydrocarbons $\left(\mathrm{C}_{5} \sim \mathrm{C}_{9}\right.$ normal alkanes, petroleum fractions, and benzene and its derivatives) using water vapor as the carrier gas and activated alumina as the stationary phase (Fig. 1). By using a steam carrier, these samples were eluted quite rapidly at comparatively low temperatures $\left(120 \sim 220^{\circ} \mathrm{C}\right)$ even with a column of activated alumina (Figs. 2 5). Samples were injected in the form of extremely diluted aqueous emulsions but the water in the sample had not influenced on the chromatograms. The retention volumes increased with the rise of the column temperature up to $180^{\circ} \mathrm{C}$ and then began to decrease (Fig. 6). This anomaly in the retention volumetemperature dependence was explained by a mechanism different from that of ordinary G-S chromatography; i.e., the sample molecules were adsorbed and were migrating on the multi-molecular water film which was formed on the adsorbent as speculated in the B. E. T. theory of physical adsorption.

(Received Sept. 3, 1970) 